\title{
Features of methane emission into the atmosphere over buried landfill bodies in urbanized ecosystems of Moscow
}

\author{
Klim Mashentsev ${ }^{1}$, Viktor Glebov ${ }^{2,1^{*}}$, Viktoriya Erofeeva ${ }^{1,3}$, Sergey Yablochnikov ${ }^{3}$, \\ Olga Mareeva $^{2}$, Saulius Mickevičius ${ }^{4}$, Dmitry Nikitin ${ }^{5}$ \\ ${ }^{1}$ Peoples Friendship University of Russia (RUDN University), Faculty of Ecology, 6 Miklukho- \\ Maklaya Street, Moscow, 117198, Russian Federation \\ ${ }^{2}$ Russian State Agrarian University - Timiryazev Moscow Agricultural Academy, Moscow, 127550, \\ Russia \\ ${ }^{3}$ Moscow Technical University of Communications and Informatics, Moscow, 111024, Russia \\ ${ }^{4}$ Vytautas Magnus University, Kaunas, LT 44248, Lithuania \\ ${ }^{5}$ Geological Institute, Russian Academy of Sciences, Moscow, 119017, Russia
}

\begin{abstract}
On the outskirts of cities landfill bodies are formed, the territories of which are later used in urban planning. Over the buried landfill soils which represent construction and household garbage, methane flows are formed, which worsen the environmental conditions of the territories and negatively affect the psychosomatic health of residents. The goal was to study methane emissions from various buried landfills in Moscow. Our study on urbanized ecosystems in Moscow revealed different methane emissions in the soils. Thus, over young landfill bodies, the concentration of methane in the soils was $8-16 \mathrm{ppm}$. This led to the release of methane into the atmosphere of the capital city. In the old landfill bodies, the concentration of methane in the soil was 1-2 ppm and did not cause methane emissions into the urban atmosphere. The analysis of the obtained data revealed the absorption of methane by soils on old landfill bodies at high and very high methane oxidation (Lobochevsky, Zyuzinskaya, Brateevskaya, Kashirskoe Highway and Ochakovka Streets). For organomineral horizons of replantozems with an increased content of organic matter and a loamy granulometric composition, increased methane formation and oxidation of autochthonous gas with undetected emission were detected.In technogenic and gray-humus horizons of urbanozems, methane formation and methane oxidation were reduced.
\end{abstract}

\section{Introduction}

The main greenhouse gas donors are energy facilities and transport. However, soils also emit large amounts of carbon dioxide and methane [1]. When large cities develop, landfill bodies are formed on their outskirts, the territories of which are subsequently used in urban planning. Intense methane flows form over buried landfill soils containing a large amount

\footnotetext{
*For correspondence: vg44@mail.ru
} 
of organic material (construction and household waste) [2]. High concentrations of methane and carbon dioxide in the atmosphere worsen the ecological situation of urbanized areas and adversely affect the health and functional of the human body [3]. They can also have a negative impact on the surrounding biodiversity [4,5]. In addition to the sanitary and hygienic damage caused to the environment by such objects, there is an even more dangerous threat. Methane generated in landfill bodies rises up and can accumulate in sealed soils under buildings built in such areas and reach a concentration of up to $5 \%$, which is a critical explosive concentration [6].

\section{Materials and methods}

The objects of the study were soils, as well as man-made surface formations over various buried landfill bodies. These objects were considered on the territory of the right bank of the Moscow River in the city of Moscow. 14 buried landfill bodies were examined, almost all of which had one or more sections laid on them, and gas-geochemical surveys were also carried out. 33 samples were taken for physical and chemical analyses, 116 samples of soilground air, and 142 samples of air of the surface atmosphere.

To assess the gas-geochemical state of the territory a gas survey was conducted, which included [7]:

- spur gas survey with soil air sampling to determine the gas concentration;

- static chamber method for determining the emission of gases from the soil surface.

Soil samples were taken to determine the activity of bacterial formation and methane oxidation. Above each buried landfill body, several points of gas-geochemical sampling of air were laid on a grid of squares.

\section{Results}

When conducting the study, we took as a reference the background concentration of methane in the soil in the studied area of the MSU park and was associated with the fact that formed soils on clean low-power bulk soils (sand) up to $1.5 \mathrm{~m}$ lie in the park [8,9]. The background concentration is $2 \mathrm{ppm}$ (Table 1). These soils were chosen as reference soils because they have the greatest similarity with the natural ones within the urban agglomeration.

Table 1. Methane concentration and emission from the soils of the MSU Park territory

\begin{tabular}{|c|c|c|c|}
\hline $\begin{array}{l}\text { Soil sampling } \\
\text { point }\end{array}$ & $\begin{array}{c}\text { Emission } \mathbf{n g} / \mathbf{m}^{2} \\
\text { per hour }\end{array}$ & $\begin{array}{l}\text { Concentration on } 60 \mathrm{sm} \text {, } \\
\text { ppm }\end{array}$ & Concentration on \\
\hline p0 & 0.03 & 2.31 & \multirow{2}{*}{ Kosygina Street } \\
\hline p1 & 0.01 & 1.93 & \\
\hline p2 & -0.03 & 2.24 & \multirow{4}{*}{ MSU Park } \\
\hline p3 & -0.02 & 1.75 & \\
\hline p4 & 0.01 & 2.05 & \\
\hline p5 & 0.00 & 2.08 & \\
\hline p6 & 0.00 & 2.45 & University Avenue \\
\hline
\end{tabular}

As a result of the gas survey to assess the gas-geochemical state of the studied territories of Moscow, the following results were obtained (Table 2). 
Table 2. Methane concentration and emission in soils above buried landfill bodies

\begin{tabular}{|c|c|c|c|c|c|c|}
\hline Territories & $\begin{array}{c}\text { Name of the } \\
\text { soil }\end{array}$ & $\begin{array}{c}\text { Methane } \\
\text { oxidation at } \\
60 \mathrm{~cm}, \mathrm{ng} / \mathrm{g} \\
\text { per hour }\end{array}$ & $\begin{array}{l}\mathrm{CH}_{4} \text { in the } \\
\text { soil, pm }\end{array}$ & $\begin{array}{c}\mathrm{CH}_{4} \\
\text { emission, } \\
\mathrm{mg} / \mathrm{m}^{2} \\
\text { per hour }\end{array}$ & $\begin{array}{l}\text { CH4 in the } \\
\text { surface layer } \\
\text { of the } \\
\text { atmosphere, } \\
\text { ppm }\end{array}$ & $\begin{array}{l}\text { CH4 in the } \\
\text { atmosphere } \\
\text { at an altitude } \\
\text { of } 2 \mathrm{~m} \text {, ppm }\end{array}$ \\
\hline \begin{tabular}{|l|} 
Lobachevsky \\
Street
\end{tabular} & $\begin{array}{c}\text { Replantozem } \\
\text { buried }\end{array}$ & 38.2 & 7.4 & -0.02 & 2.7 & 2.4 \\
\hline \begin{tabular}{|l|} 
Tsyurupy \\
Street
\end{tabular} & \begin{tabular}{|c|} 
Urbanozem \\
with low- \\
power, \\
strongly stony
\end{tabular} & 0.0 & 2.6 & 0.01 & 1.9 & 1.7 \\
\hline $\begin{array}{l}\text { Yasnogorskaya } \\
\text { Street }\end{array}$ & $\begin{array}{l}\text { Urbanozem is } \\
\text { low-power, } \\
\text { strongly stony }\end{array}$ & 22.1 & 0.9 & 0.00 & 1.0 & 0.9 \\
\hline \multirow[t]{2}{*}{$\begin{array}{l}\text { Ochakovka } \\
\text { river }\end{array}$} & $\begin{array}{l}\text { Low-power } \\
\text { urbanozem }\end{array}$ & 3.6 & 11.7 & 0.00 & 2.3 & 2.6 \\
\hline & \begin{tabular}{|c|} 
Urbanozem \\
with low- \\
power, \\
strongly stony
\end{tabular} & 6.2 & 7.2 & -0.06 & 2.3 & 2.2 \\
\hline $\begin{array}{l}\text { Brateevskaya } \\
\text { Street }\end{array}$ & Litostrat & 10.8 & 2.5 & 0.00 & 2.8 & 2.5 \\
\hline \multirow[t]{2}{*}{$\begin{array}{l}\text { Ryabinovaya } \\
\text { Street }\end{array}$} & \begin{tabular}{|c|} 
Lithostrate \\
with signs of \\
soil formation \\
\end{tabular} & 0.0 & 3.7 & 0.00 & 4.9 & 4.0 \\
\hline & $\begin{array}{l}\text { Low-power } \\
\text { urbanozem }\end{array}$ & 6.1 & 3.9 & 0.02 & 3.3 & 3.6 \\
\hline \begin{tabular}{|l|} 
Skolkovskoe \\
highway
\end{tabular} & \begin{tabular}{|c|} 
Lithostrate \\
with signs of \\
soil formation \\
\end{tabular} & 0.4 & 33.3 & 0.13 & 1.7 & 4.9 \\
\hline $\begin{array}{l}\text { Zyuzinskaya } \\
\text { street }\end{array}$ & $\begin{array}{l}\text { Low-power } \\
\text { Urabnozem }\end{array}$ & 21.4 & 2.7 & 0.02 & 2.0 & 2.3 \\
\hline $\begin{array}{l}\text { Nagornaya } \\
\text { Street }\end{array}$ & Litostrat & 0.0 & 3.3 & 0.01 & 3.4 & 2.4 \\
\hline \begin{tabular}{|l|} 
Akademika \\
Millionshchikov \\
Street
\end{tabular} & \begin{tabular}{|c|} 
Urbanozem \\
low-power \\
strongly stony
\end{tabular} & 0.5 & 2.6 & -0.01 & 2.2 & 2.4 \\
\hline \begin{tabular}{|l|} 
Obrucheva \\
Street
\end{tabular} & $\begin{array}{c}\text { Replantozem } \\
\text { buried }\end{array}$ & 0.0 & 2.6 & 0.00 & 2.2 & 2.2 \\
\hline Tallinn Street & \begin{tabular}{|c|} 
Lithostrate \\
with signs of \\
soil formation \\
\end{tabular} & 0.0 & 2.5 & 0.02 & 2.4 & 2.6 \\
\hline
\end{tabular}

The comparative analysis of methane emissions from buried landfill cases in the framework of the identification of gas-geochemical hazard (potentially dangerous concentrations-CH4 $<0.1 \%$ in the thickness of the landfill body) showed the following results. There were identified objects (Ryabinovaya Street, Skolkovskoe Highway, Yasnogorskaya Street) where there was an intense methane emission. On the Skolkovsky Highway, the maximum methane emission into the atmosphere at one of the gasgeochemical survey stations reached values of $3.24 \mathrm{ng} / \mathrm{m}^{2}$ per hour.

This is due to the fact that the landfill was closed recently, is located in a flooded area, there is no methane oxidation in the soil-soil profile, and its value is zero. The 
concentration of methane in the soil at $60 \mathrm{~cm}$ has high values, which reach $33.3 \mathrm{ppm}$.

The landfill body on Ryabinovaya Street was also buried recently, but it is located in a non-flooded area and has an average methane oxidation inside the soil-soil profile (6.1 ng / g per hour). However, the methane concentration at a depth of $60 \mathrm{~cm}$, although higher than the background values, is significantly lower than the concentration on the Skolkovo highway. Its maximum value at one of the gas-geochemical stations for sampling soil air was $6.3 \mathrm{ppm}$, and the average methane emission into the atmosphere over the entire surface of the buried landfill body was in the range from 0.02 to $0.12 \mathrm{ng} / \mathrm{m}^{2}$ per hour and was an order of magnitude lower than at the Skolkovsky Highway.

The dump body on Yasnogorskaya Street was buried a long time ago, and belongs to the old ones. In this regard, well-formed soils are located above it. The soil layer has a rich pool of methane-oxidizing bacteria that are able to capture methane at the depth of the soil profile. As a result, intense methane oxidation occurs here, the values of which reached $22.1 \mathrm{ng} / \mathrm{g}$ per hour. Also, the absence of flooding contributed to such a high value of methane oxidation. However, the concentration in the soil layer was very small - its maximum value at one of the stations of gas-geochemical sampling of soil air was only 1.3 ppm, which is almost twice less than the background value. As a result, the emission of this buried landfill body is minimal in the compared series of gas-geochemical potentially dangerous buried landfill bodies and varies from -0.01 to $0.01 \mathrm{ng} / \mathrm{m}^{2}$ per hour.

The methane concentration inside the soil-ground layer at a depth of $60 \mathrm{~cm}$ is residual. Autochthonous and allochthonous methane was subjected to bacterial oxidation [10]. Subsequently, the concentration of methane in the soil column also affects the emission of gas into the atmosphere. A map of methane concentrations at a depth of $60 \mathrm{~cm}$ in soils and over buried landfill bodies were constructed on the map of flooding of the Ecological Atlas of Moscow.

\section{Conclusions}

Thus, the conducted study on the assessment of methane emissions into the atmosphere over buried landfill bodies in urbanized ecosystems of Moscow gives grounds to draw the following conclusions:

1. At a depth of $60 \mathrm{~cm}$, powerful biogeochemical barriers are formed in the soils and over old reclaimed landfill bodies, preventing methane emissions into the atmosphere.

2. The residual methane concentration in the soils and over the young landfill bodies was $8-16 \mathrm{ppm}$, which caused methane emission into the city atmosphere. In the old landfill bodies, the concentration of methane in the soil was 1-2 ppm, preventing the emission of methane into the atmosphere.

3. The maximum release of methane into the atmosphere from the area of anthropogenic soils: over a young buried landfill body on Skolkovsky Highway was 0.67 tons per summer in the absence of methane oxidation; the average release- $0.03-0.01$ tons per summer - on buried landfill bodies of various ages on Ryabinovaya and Obrucheva streets with average methane oxidation.

4. The absorption (runoff) of methane by soils on old landfill bodies at high and very high methane oxidation (Lobochevsky, Zyuzinskaya, Brateevskaya, Kashirskoe Shosse and Ochakovka streets) was revealed.

5. For organomineral horizons of replantozems with an increased content of organic matter and loamy granulometric composition, increased methane formation and oxidation of autochthonous gas were detected, with undetected emission. In technogenic and grayhumus horizons of urbanozems, methane formation and methane oxidation are reduced. 


\section{References}

1. N.G.Phillips, R.Ackley, E.R. Crosson et al., Environmental Pollution, 173 1-4, (2013)

2. J.P.Kaye, I.C.Burke, A.R. Mosier, Ecological applications, 14(4), 975-981 (2004).

3. Y. Mayorova, V. Glebov, V. Erofeeva, S. Yablochnikov, B. Laver, E3S Web of Conf. 169, 04004 (2020)

4. O. Maslennikova, V. Erofeeva, E3S Web of Conf. 169, 04002 (2020)

5. V.V. Erofeeva, O.V. Maslennikova, Hygiene and sanitation, 8, 897-902 (2019)

6. D. V. Ivanov, Izvestiya vysshikh uchebnykh zavedeniy. Geology and exploration, 4, 63-67 (2009)

7. G. A. Alexandrov, M. A. Sokolov, A. L. Stepanov, Soil science, 10, 1192-1194. (1996)

8. V. M. Semenov, I. K. Kravchenko, T. V. Kuznetsova, et. al., Microbiologiya, 73(3). 423-429 (2004)

9. O. Yu. Goncharova, O. V. Semenyuk, G. V. Matyshak, A. A. Bobryk, Moskow University Bul. Series 17: Soil Science, 2, 3-10 (2016)

10. Interaction of soil and atmospheric air. edited by B.G. Rozanov (MSU Publishing House, Moscow, 1985) 